\title{
Miranda
}

Revue pluridisciplinaire du monde anglophone /

Multidisciplinary peer-reviewed journal on the English-

speaking world

$17 \mid 2018$

Paysages et héritages de David Bowie

\section{Hackney by Night}

An interview of David George and Umut Gunduz

\section{Isabelle Keller-Privat}

\section{(2) OpenEdition}

\section{Journals}

Electronic version

URL: http://journals.openedition.org/miranda/13553

DOI: 10.4000/miranda.13553

ISSN: 2108-6559

\section{Publisher}

Université Toulouse - Jean Jaurès

Electronic reference

Isabelle Keller-Privat, "Hackney by Night", Miranda [Online], 17| 2018, Online since 21 September 2018, connection on 16 February 2021. URL: http://journals.openedition.org/miranda/13553 ; DOI: https:// doi.org/10.4000/miranda.13553

This text was automatically generated on 16 February 2021

\section{(c) (†) $\odot$

Miranda is licensed under a Creative Commons Attribution-NonCommercial-NoDerivatives 4.0 International License. 


\title{
Hackney by Night
}

An interview of David George and Umut Gunduz

\author{
Isabelle Keller-Privat
}

1 David George is a British photographer who has exhibited in solo and group exhibitions internationally. He has been making photographs since 1980 and was awarded an MA (distinction) from The Sir John Cass School of Art, London in 2009. He currently lectures and runs master classes on available light and alternate/archival photography at Universities in the UK. In 2009 he co-founded Uncertain States Project which promotes alternative platforms for contemporary British photography. He lives and works in London.

2 David George's current exhibition, London by Night, is on view at the Museum of London until October 2018. Previous solo exhibitions have included Elsewhere / Peckham 24, London, 2017, Extravagant at Minerva House, London, 2017, and The Broken Pastoral, Sid Motion Gallery, London, 2017. Recent group exhibitions have included Uncertain States Annual Show, The Arts Pavillion, London, 2016 \& 2015 ; After London, Bank Gallery, London, 2016 ; Legend of The East End, 2015. A retrospective of his work can be accessed on his website : http://www.davidgeorge.eu/index.html

David George's work has recently been included in The Observer, Photomonitor, The Evening Standard, British Journal of Photography and The Sunday Times Magazine, as well as in publications such as Archive, Imagining The East End (Black Dog, 2013).

David George's monograph Hackney by Night, was published by Hoxton Mini Press in 2015.

In November 2017 he took part in the international conference Suburbia-an archaeology of the moment that was hosted by the CAS, the research centre on the English-speaking world at the University of Toulouse 2 - Jean Jaurès, where his presentation on "The Broken Pastoral," based on a projection of some of his artwork, aroused keen interest.

In Spring 2018 George's monograph Hackney by Night inspired London born and Margate based filmmaker Umut Gunduz with an art video that can be accessed on https:// vimeo.com/256941355. Umut started his career as a sound designer working on short documentaries and films. His work is a blend of portraiture and fiction, exploring his 
subject matter with a sensitivity for storytelling and imaginative expression. At the present, he is beginning to write fiction and non-fiction films and has kindly agreed to take part in this interview.

Isabelle Keller-Privat: First of all, allow me to thank you, David, for the generosity and patience with which you have welcomed this interview and which made our conversations in Toulouse, last November, so stimulating. On that occasion, you told me that you initially started out as a painter: could you relate what triggered this shift? Are there specific painters that you still consider crucial to the development of your photographic art?

David George : I initially wanted to be a painter, which is a long way short of actually being one, but still have a keen interest in painting. I have based some of my series around ideas from $19^{\text {th }}$ century western art such as the Sublime, the Uncanny and the Romantic. The Romantic series being directly inspired by Bocklin's "Isle of the Dead" paintings. As to being "crucial" to my art, I'm not so sure, but paintings and literature do feed into my practice in a way photographs do not. I like the idea that when I look at a painting, I am witness to the thousands of small decisions made by the artist as indicated by the brush strokes that go to make up the finished image. It is not something I can really find in the photographic print to the same extent, and I find it allows empathy with the creative process of the artist.

IKP: The titles of your exhibitions evince a marked interest in the representation of space and in the complex relationships between rural and urban spaces : Enclosures, Badlands and Borders, Backwater or The Broken Pastoral offer the viewer a very personal and singular perspective upon apparently meaningless and banal places where the limits between manmade and natural scenes often overlap. What draws you to these protean, sublime and derelict, out of the way suburban places?

DG : I grew up in the industrial North East of England so these were the landscapes of my childhood. They seem as natural and wonderful to me as probably glaciers to Norwegians, Highlands to the Scottish, or the Alps to the French. I understand how they came about, how they function, but most of all how fragile and transient they are, so I take great pleasure in capturing them as photographs before they vanish and are replaced. This disappearance and replacement happens with a remarkable regularity.

I do not see them as banal, they have a reason and a purpose to exist and therefore possess a certain distinct energy and while they are in no way bucolic or romantic in nature, they possess their own unique beauty. 


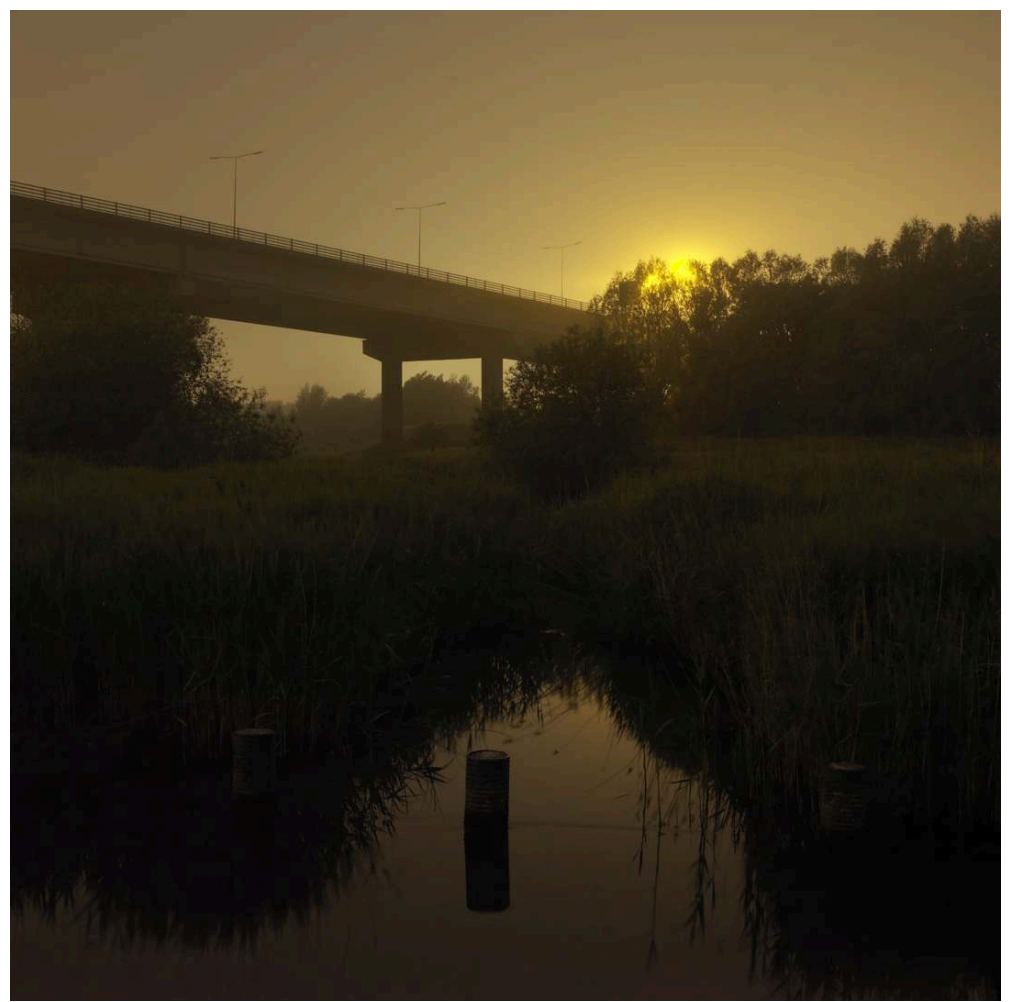

IKP: Not only do you choose disregarded places but you also choose the very time of inattention to create your photographs : night time, when you only come across silent and marginal night dwellers : is this because darkness makes everything clearer in your mind's eye?

DG : I enjoy the solitude of the night ; it gives me time to examine things closely and carefully. There is no appointment to meet, my phone doesn't ring, and time, somehow, becomes more liquid-the hours drip away unnoticed. I enjoy working at night as it adds another element to the photographing of these places that does not exist during daylight hours. This extra element contributes to the creation of a romantic dystopia, which though almost a contradiction in terms, is the best way I can describe what happens when all these elements combine in the photograph.

So in a way, the darkness does make me see things a lot more clearly.

IKP : A few months ago, a recent video made by Umut Gunduz, and based on your latest opus, Hackney by Night, was released. It retraces the photographer's steps as well as the storyline of Karen Falconer whose words provide the reader/viewer with a fictitious narrative foregrounding the haunting essence of these night photographs. The short film enhances the eerie resonance of words and images. Could you tell us more about the origins of this project?

DG : The project was Umut's idea. He saw a newspaper article about the Hackney by Night book and contacted me with the idea of making a film or documentary based around the book. I thought it would be really interesting to take the idea of the book and re-interpret it in a new way. My only input was to suggest the voice over was made with a Scottish female and suggested Valerie Gogan as someone who might fit the bill. Umut was responsible for every other element within the film.

IKP : I am most thankful to Umut Gunduz for having decided to join in and shed some light on his beautiful video. Your short film interestingly alters the focus by foregrounding the photographer's art and showing us what is precisely hidden behind the photograph : the camera's eye. Could you tell us more about this puzzling mise en abyme whereby the 
photographer's eye is refracted in the cameraman's, and eventually in the viewer's ad infinitum? Could you explain the reason for the close ups on the photographer's face and hands?

Umut Gunduz: I spent some time chatting with David prior to doing any filming. I wanted to know what drove his inspiration to create his photos. Quickly, I realised that my attraction to David's work was because of the similarities we shared in our perspectives on quiet places and the eerie sublime of the night. I wanted to capture that intense focus and attention to the sound and light you get when being out at those witching hours.

However, I wanted to keep an element of mystery about the photographer. I didn't want to distract the audience from the voiceover's narrative and the photo stills. Before I start any filming or editing, I try to establish my boundaries and concepts so I can better refine the way I approach each process. For example, I decided I would shoot on one fixed lens-a $50 \mathrm{~mm}$. This lens is not only good in low light, but it requires that I move in and out of my subject matter to frame my shots (there's no zooming in and out-I must physically move). Because of the very shallow depth of field required for a video camera to operate in such low light, my movements had to be sensitive to my area of focus-any slight movement would throw the object of my intention out of focus. This meant I could respond energetically to what I was feeling whilst walking with David. I felt the solitude and level of deep focus and responded to that. I had decided that we were not to talk to each other much either until after the filming. That elevated sensitivity to what was going on and also meant our sound field was nicely captured. I had decided I would not reveal a face or anything else that would give the audience a reason to attach themselves to David emotionally, so I captured details of actions by human hands detached from a face with eyes. That gives the audience a new set of eyes in many ways (the camera's, their own, the filmmaker's, etc). In this way, David's role echoed mine. He was an investigator, someone travelling through time, space, and place, capturing photographs of places that held dear memories.

I am deeply moved by buildings and spaces and their relationships to memories so this project made absolute sense to me as I thought I had something I could offer. Imagine the amount of memories a single space has captured... 


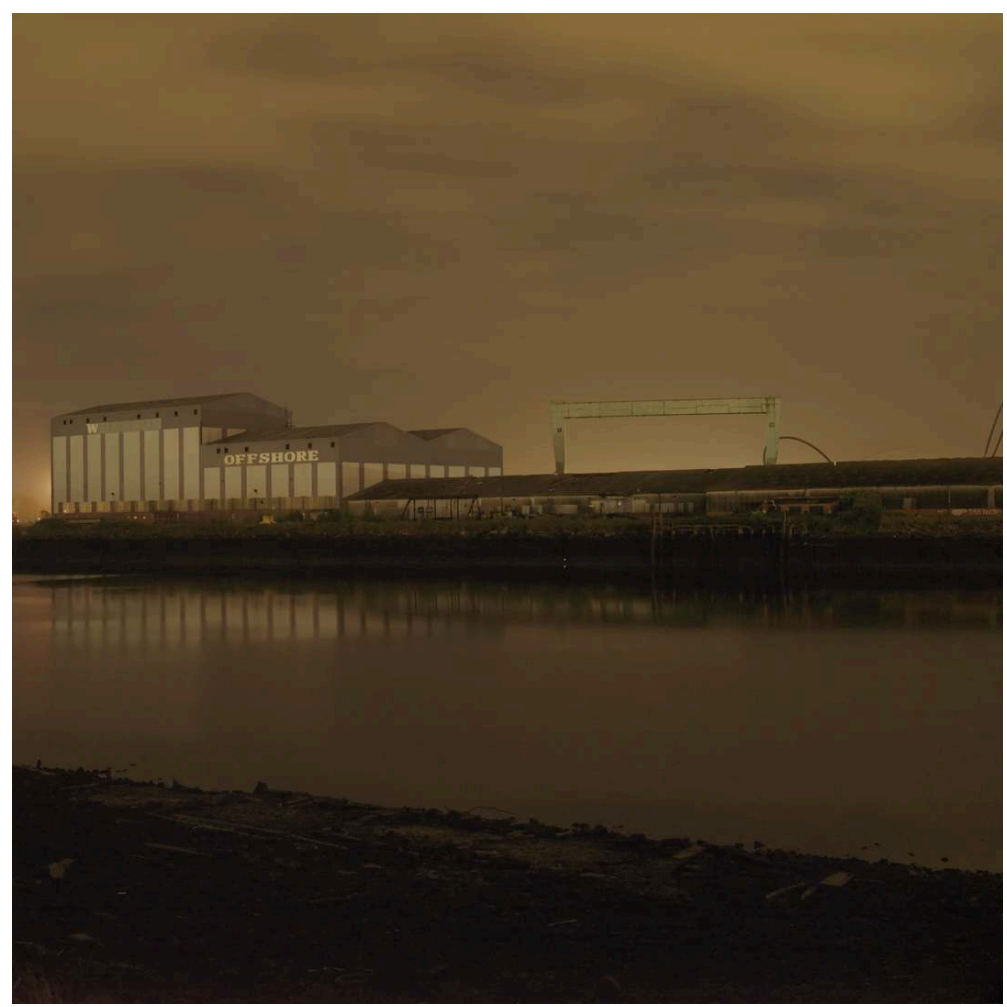

IKP: Amongst the many eyes, or forms of presence that contribute to the viewer's fascination there is the stray cat wandering in and out of the focus of your camera, just after the "stray piece of litter drifts across the road." What is the role of the cat here ? How does this chance encounter suggest a new realm where the non-human opens up a new awareness of our surroundings? How does it connect with the song of morning birds leading the way from night time into dawn at the end of the film?

UG : I used to go walking with my cat in the very early hours of the morning. There is a secret world that exists at that time of night. That world is a quiet one-where miniature beasts roam in search of all sorts of mischief. Cats, in particular, are the most silent and welcoming. A night out nearly always chances upon a cat that will either run from you or approach with a welcoming meow. And cats are creatures of magic too ! Suggesting omens and the like-as in fables of old. They are the walkers of the night realm, the shepherds to the wanderer. The comforting pit stop. It's all very subjective.

Nature is ever present in urban areas. The night could be seen as the unknown or the shadow world-a world behind the immediacy of the day's activities. The daylight can be seen as awareness, a delivery from the unknown dangers the night can bring. The birds herald that light in alerting all beasts (man or otherwise) that the cover of darkness is over; the realm of the visual is about to begin. 


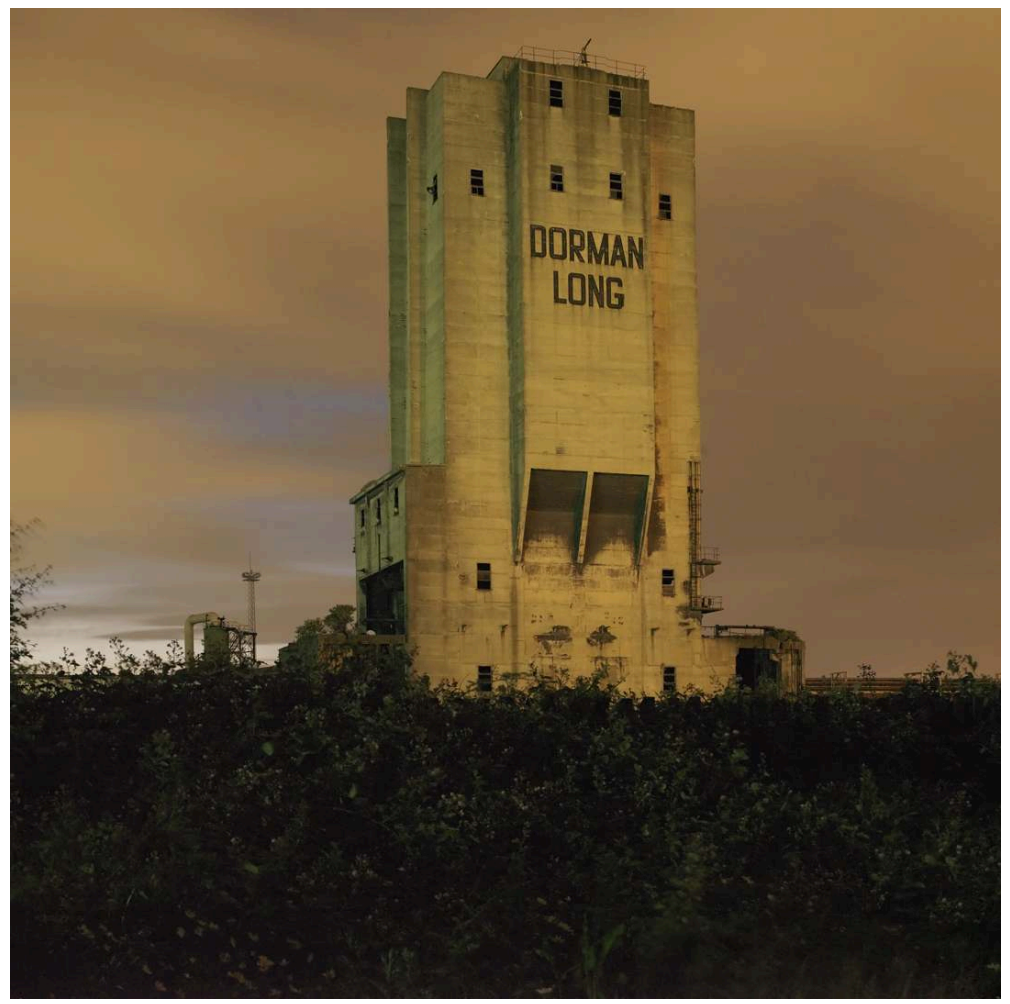

IKP : When reading David's book and watching your film one cannot fail to be struck by the distinct mood and tone that emerge from your work. Could you tell us about the directing of the actress, Valerie Gogan, who gives the film a complex note of distance and nostalgia and the necessary textual changes that a female voice implied?

U.G. : David suggested the use of Valerie right at the start of the project. I think it was purely an aesthetic and talent-based choice. This gave rise to new ideas within our piece. Originally, the text would suggest an older brotherly figure, so having a female role here would mean changing that context. But that was a very good thing! In my film, the photographer is present, there to be seen, and, as a result, plays a narrative role. But, as explained, I didn't want this role to play an emotional narrative but more that of a night walker, a wanderer, the audience. Having a female VO meant I could distance the text from David-the brotherly element would be substituted for a sisterly one in the text and so give us our separate narrative element. Great for helping to split the mind across the narratives and add to that dreamlike feel.

The tone of a piece is arguably one of the most important aspects to a film. It gives us ambience and a context to emotionally absorb the film's imagery and sound. I find that the best tones in films create a dynamic between the narrative text and imagery and the emotional content. If we see a dark image, and hear a lonely sound effect, we immediately get a sense of dread or similar. If the VO content is ambiguous but I then play it with dread or melancholy, I will hit the same note as the rest of the experience in the video. And, my film becomes monotone with very little room for the power of ambiguity in the text. But, if I play a higher note, a playful one for example, then I am juxtaposing the image and text with that of the vocal tone and delivery and so I enhance that ambiguity. That gives my audience a space to play within and contribute to what they are watching through their own projections. I like that.

And so, I told Valerie to deliver the piece as though it were being told to her imaginary sister in the film-a final letter, if you will, to a loved one. And so, I felt 
that whilst it was easy to play the ending as something dreadful and sad, it was far more enriching to play it as something positive and open. In books, the reader does all of this in his own head. In a video, I need to make these choices and play with something different-play with time.

IKP : You said to me that, contrary to the pessimistic tone of the book, the film ends on a female character that seems to be "leaving the feelings of the past for an optimistic future." How relevant is this move to the context of the suburbs where characters seem to be imprisoned behind concrete walls which in fact turn into the crucible of unheard memories? What is the role of light and shadow in the slow transformation of inanimate objects such as building blocks, walls, pavements, or window frames, into live things?

U.G. : I love the transitory nature of light and shadows. They play across objects and solid things, creating new forms and boundaries that then disappear in an instant! Windows are like TV sets for me. The windowsill becomes a kind of perch in which to watch the TV set of life happen in front of you. All of these people have lives, histories, memories, ideals for the future-and an impact on the world. Yet, we always search for the grand, the immediately amazing or the enticing. Often, in neglect of our own existence, or at least through lack of judgement. We are a starstruck society that worships TV born idols and grand ideas. But, I think it was Tom Waits who said "we are just monkeys with money and guns." So our ideas pull us further and further away from the essence of being and the imprint we leave upon our own worlds and the greater environment. When a shadow is cast from an object, that object makes an impression on the landscape and changes many things about it. That shadow reflects the movement of time/light and reminds us of the essence of every little thing, of its impact, whether it is large or small. And that behind everything there is a story that exists in time.

IKP : At one point in the narrative, we hear Valerie Gogan reading : "I begin to see there is no such thing as a solid foundation." How appropriate do you feel this sentence is to the kind of work you are doing with the suburbs, staging the unremarkable and the trivial into a new form of hospitable common ground?

UG : Everything is transient. Nothing is permanent. And so, we must live in the things as they are now and appreciate (or not) them for what that means for you and others. Foundations are an ideal and just the starting point to something else. A foundation could begin at any stage of someone's life-it's down to you as when you felt it started. And so, it's an illusion. Therefore, nothing is remarkable and nothing exists without something existing before it-so who should we pay homage to for these gifts? The chicken or the egg is another version of this. It's a wormhole.

IKP: Throughout the video, you give the viewer the impression that he is not only "on a journey through time and place," as Karen Falconer puts it, but also on a journey through the arts. Your experience as a sound designer and the years spent recording sound on drama sets probably account for your sensitive approach to intermedial art work. This video is particularly striking in the way it blends photographs and filmed sequences where the setting unfurls at an odd angle in a fast tracking in. How relevant is the specific context of the suburbs to the creation of such hybrid art forms?

UG : In photographs I see movement. And in video I see stillness. I wanted those things to be interchangeable. Memories are timeless in the way we access them. But video is not-video happens in time. But then video adds new memories to the viewer after they have experienced it. What is most important about a film is the way it is remembered by the viewer-the way it haunts the mind of the person who has watched it. I like to raise questions that the viewer must answer for themselves-like 
solving riddles of their own, because this highlights the amount of projection that goes on when someone is watching a film.

Suburbs hold generations of memories. During the day, with the buzzing of the cities and the movement of people and bright light, it is easy to get caught up in it all. But at night, the echoes of the day and the many days that have passed show within the crevasses of light and the markings on the concrete and walls. The trees hold whispers and the winds carry tales. This is the magic of night. It is the reflection of the day's events. I worked the sound to subtly give rise to the point when the story and the images begin to crossover. I had many worlds to contend with-the world of David, the world of the narrative voice and the world of the film's narrative. Sound is very good at helping the viewing enter the worlds from various angles. The sound world of the photos is relatively silent with no sound at all at the start, whereas David's world has fixed sound to the image-diegetic sound-that helps us be present for his actions to begin with. Slowly, as the film develops, these sound worlds begin to overlap and unfold into one another, fusing the photos and the moving images into one path. For me, this moment is triggered by David's loud shutter sound and the image of the high rise apartment, repeated for the second time. After this point, the actions of David, the photographs and the voiceover become a single story (I hope !) in the viewer's mind and this helps create that feeling of a fractured dream (which is of course what most people are doing whilst David is out doing what he does !).

IKP : May I ask you, Umut, to comment upon the necessary temporal shift that derives from the conversion of a series of photographs into film? What technical choices did you have to make in order to preserve and enhance the meditative essence of David's images?

UG : As for the temporal shifts, I worked mostly intuitively. I needed to give enough time for each image to be absorbed but not so much that the image become too important in the viewer's mind. I wanted us to make a fleeting pass through the imagery but still gain a sense of place and atmosphere. I wanted the images to support the voiceover narrative by not necessarily illustrating directly but by giving the words another dimension (as the book does so well !). I wanted the same private space you get from reading the book to be evident here as best as possible. But it couldn't be too long! I knew it had to be over with earlier than I wanted and so I was forced to make tough choices on the flow of these images, sometimes losing shots I loved for the sake of the whole experience. The film has cycles but it also needs to move ahead and develop as a story. If I had spent too long on any one part, I'd have lost my watcher. The rhythm in this film is determined largely by the voiceover and the way it punctuates the images-whether they be still or moving.

IKP: Thank you so much Umut for this illuminating exploration of the specificities of your art and its intimate connections with David's photographs.

I would now like to turn again to David's work, and more specifically, to the fascinating talk he delivered on "The Broken Pastoral" in November 2017 at the University of Toulouse. One of the recurring references which struck me during your talk, David, was to Patrick Keillerwhich led me to assume that your photographer's eye has long been influenced by film making. In his book The View from the Train, Patrick Keiller explains that what attracted him to the medium "is that it offers the possibility [...] to experience non-existent spaces" and he argues that "spaces that have not yet been produced might exist physically, but not experientially or socially", so that "film space can offer an implicit critique of actual space."1 In Broken Pastoral and Elsewhere I Peckham you portray landscapes on the verge of disappearance: power stations and gasometres, barren expanses about to be destroyed 
that endow your work with a perceptible nostalgia. Would you say that photography, like film, is a nostalgic and creative gesture with a critical edge? Would you agree with the idea that the singular, disruptive temporality of photography that necessarily induces a pause in the onrush of everyday life, accounts for its meditative endurance and strength?

DG : I think, perhaps, I am enchanted by the obscured fragility of these landscapes and places. That is to say, when I was younger these places were fixed, permanent points in my personal universe, the ship building, mining, steel manufacturing, hydrocarbon distillation and nuclear power generation plants dominated my childhood landscapes and aesthetics.

To me these places had always and would always occupy the same place in my social, political, cultural and personal landscapes. As the means of generating power changed, manufacturing declined alongside the reduction of our dependence on hydro carbons and the way we used the land in the late $20^{\text {th }}$ century changed, so these landscapes became arcane and obsolete and began to disappear.

I found that I was, if accidentally, not only recording things I perceived as solid becoming ephemeral in a strangely covert manner, but that I was also witnessing and recording the end of the industrial revolution in Western Europe, something I never envisaged nor expected. These places I had once seen as solid and permanent have now become strangely tenuous, fleeting and fragile, a feeling I hope feeds through in the work.

As for the nostalgia in the images, I personally feel that photography is always about the past. As soon as you press the shutter; the moment is gone and is recorded history. The "now" has just become the "past" no matter if that history is a fraction of a second old. Consequently photographs can only talk about the future, or the present, in terms of what has gone before. We must also decide whether we are talking about reflective or reconstructive nostalgia. I am interested in the idea of reflective nostalgia within the work I make, but I have no interest in restorative nostalgia as a tool for the reading and understanding of the images I produce through the element of romanticism I inject into the work. This could be misread as restorative nostalgia. But ultimately, the images, as I said in the "Broken Pastoral" exhibition and talk, are not a lament for what is being lost, but a celebration of the new landscapes that are being created. 


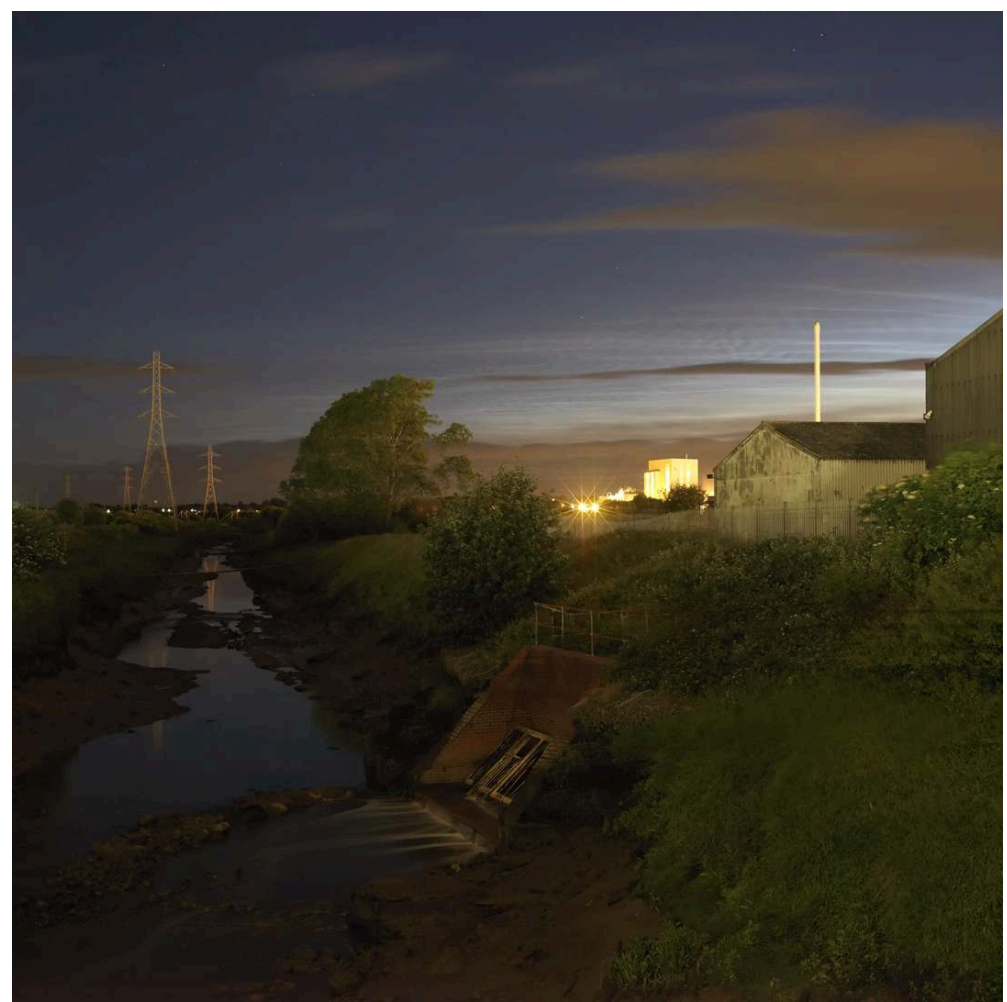

IKP : When watching your night photographs of closed warehouses and factories or distant blocks of flats under the eerie glare of street lights one is tempted to recall David Gascoyne's Night Thoughts and the character of the nightwalker on the lookout for "something that hovers, maybe hovers only just beyond the rim."2 Could you tell us, David, how this tallies with your definition of the photographer's role? Do you consider yourself as a witness to what is usually left in the dark?

DG : I don't really see myself as a witness to what is usually left in the dark. I suspect that some of the subjects I want to look at, as in astronomy, are best observed in the dark. The stars are still in the firmament during daylight hours-we can't discern them. I do like the notion of something being out of site-hovering "just beyond the rim." That sense of the unknown just around the corner adds to the strength of narrative in any work. It allows the viewer's imagination to take control of the narrative within the photographic print.

IKP: The delicate effulgence of the nightly halo that suffuses your photographs endows your landscapes with a poetic undertone that sets them apart from real life scenes and I suppose that if I were to walk around Hackney at night-which I am seriously considering now !-my perception of outlines, colours, and textures would be entirely altered by your work. I am thinking in particular of the bench in the underpass which you have transformed into an object of desire at the centre of the picture, glowing with possibilities of mysterious rendezvous or whispered secrets. Would you say that the photographer's art, in your case, is 
similar to the poet's who sketches out a new way of being in the world? Have any specific poets and writers influenced your perspective on the city?

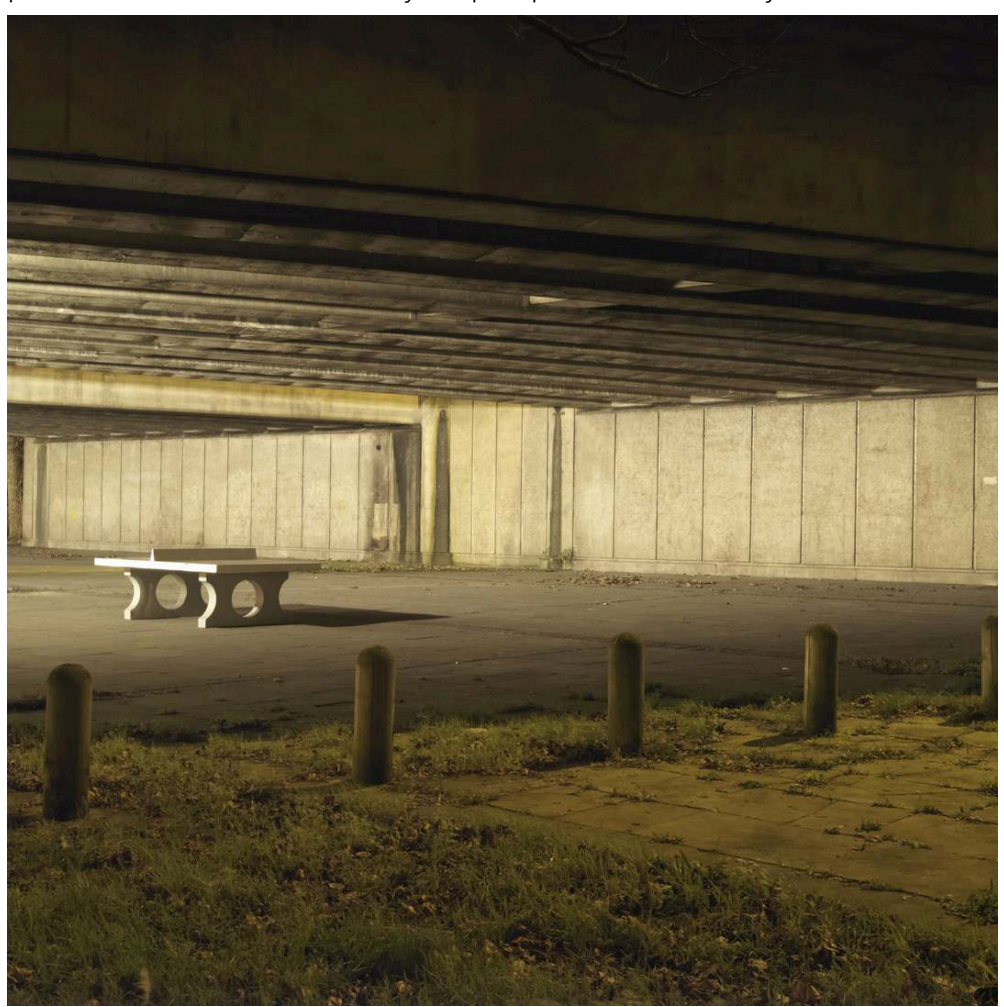

DG : I think photography can be lyrical, but in terms of photographing the city I think I apply the same sensibilities to it as I do to large natural expansive landscapes or claustrophobic interiors. I only ever try to work with the available light to give an, albeit subjective, representation of what is in front of me when I make the photograph. I must admit that Cormack McCarthy has been a big influence on my work, especially his Border Trilogy in which the landscape becomes an integral character in his plot narratives. 
IKP : Could you tell us about the technical and material difficulties of night photography and long exposure? How does this influence your choice of material in the production of images? How does this define your relationship to photographic practice?

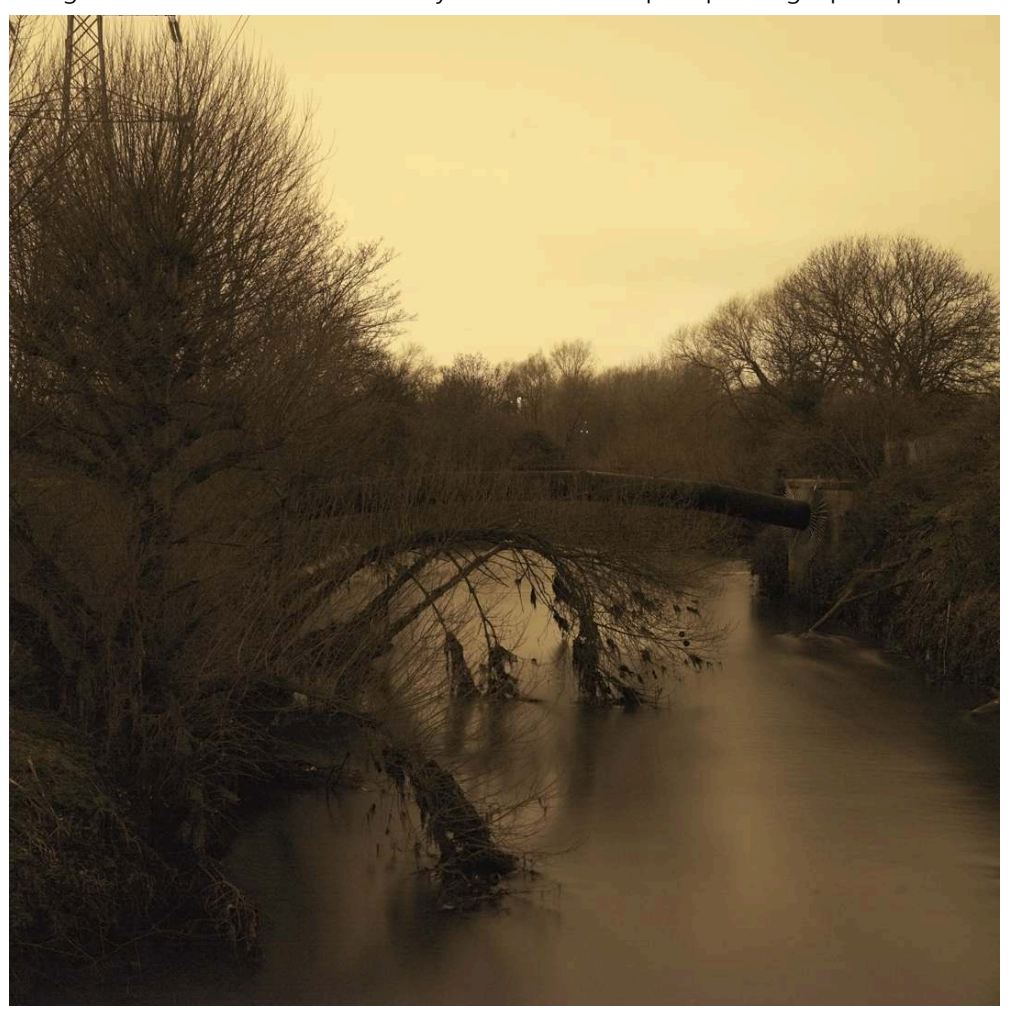

DG : I use digital capture for my night photography as it handles low light levels much better than film because it has no reciprocity failure problems so my exposures are much faster and more accurate. Also I can check the histogram of each shot as I take it and adjust the exposure accordingly. Apart from a little white balance and noise reduction, the images are pretty much how they came out of the back of the camera. I always use as little postproduction as possible as it is very easy to destroy the spontaneity of an image by overworking it on Lightroom or Photoshop; I also prefer the honesty of an un-manipulated image. A photograph either works or it doesn't and no amount of postproduction manipulation will make it work or give it any soul. That is not to say I am against postproduction technologies, though I do have mixed feelings about them, but without sounding like a Luddite I think they are just another tool in the photographer's toolbox rather than a cure all for any photographic malady. Ultimately they are just another small step in the evolution of photographic practice. It has never been easier for people to take photographs, digital technologies have made photography a truly democratic art form, but it is just as difficult to take a good photograph as it ever was. 


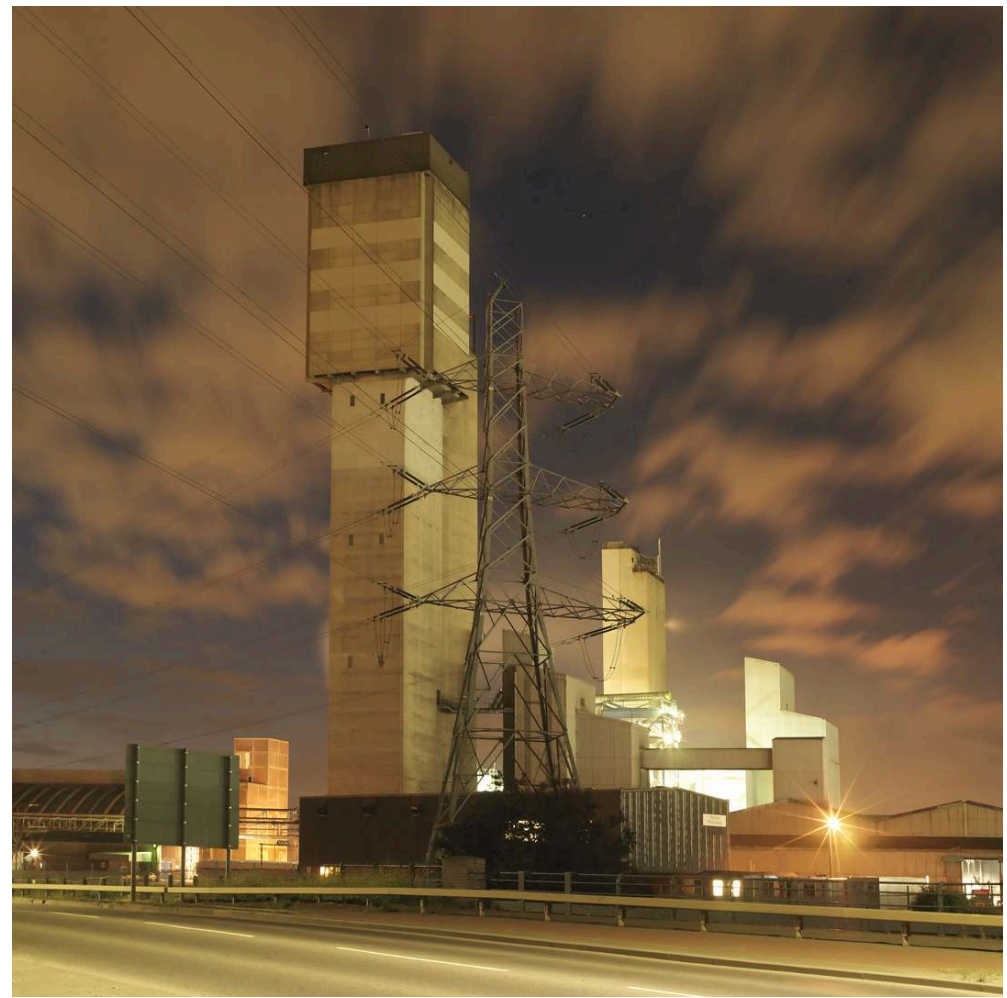

IKP: In you series "Shadows of Doubt" you select buildings and places mentioned by Hitchcock and turn them into haunting and unsettling places that inevitably bring back into the viewer's minds evocative Hitchcock scenes, so that your photographs are oddly endowed with an implicit narrative subtext that develops like a silent film. This narrative subtext becomes explicit in Hackney by Night. How would you define the relationship between words and photography in your work? Do you walk around, camera in hand and story in mind when you set out at night or does the silent storyline slowly evolve afterwards, when you begin to order and entitle the series?

DG : I think text with photographs can be a mixed blessing so I never entitle images in a series but just number the prints. Putting titles on images can lead the viewer to think or imagine when viewing the image. I think the stories we tell ourselves sometimes can be more engaging than the stories other people tell us. Obversely, I always give the series a title, which I can use to entitle any of the images by adding a number. The titles for the series are usually formed during the taking of the pictures and later become a useful editing tool. If I can't use the title of the series as a title for a photograph (no matter how much I like it) I remove it from the mix. It is a simple, but very effective way, of editing out images. I usually write the context at the end of the editing as a way of making sense (chiefly for myself) of what I have achieved, but it can often turn into something more interesting when morphing into something else. I also tend to keep the text away from the images when I exhibit, so the viewers are invited to view the text, if so inclined, if they find the images of interest to them.

I always go into a shoot for a series with a loose idea and an open mind and just allow things to transpire within the photographs. I am also a great believer in the old saying “'How do you make God laugh ?' 'Tell him your plans !'” So I tend to be tight in logistics but hopeful in outcome. In summary, I try not to over-think things and have a generosity of spirit towards the accidental.

IKP: Could you tell us more about your conception of shadows in your work? The philosopher Roberto Casati, who has published a fascinating study on the enigma of 
shadows ${ }^{3}$, shows how shadows stand, in many legends and myths, for the vital part of the body that must be preserved and protected. One may think, for instance, of Peter Pan's shadow trapped in the window. In your photographs, in particular in the series London by Night and Broken Pastoral, shadows are significantly placed in the foreground and act as a threshold leading the viewer's eye towards the heart of the image: they are shadows of streetlamps, bridges, railings, trees, or bushes. Could you explain why shadows are given such a central role in your work? Do they stand for an unnameable, uncircumscribed presence? Should they be seen as the tangible proof that there are no such things as "empty spaces...abandoned places" as the song goes, just as there are no "badlands" as you showed in your 2016 exhibition Estuary English?

DG : I think the shadows, in my work at least, are the places where imagination can play, perhaps an allotment in which to safely allow your fears and anxieties to blossom and grow for a short while. Going back to what I said earlier, the shadow offers the viewer imaginative access to the image and therefore ownership of the narrative within the photograph, the viewer becoming an active storyteller rather than a passive observer, which is a much more interesting way to interact with the photographic image.

IKP: Your work testifies to a sharp awareness of British geography, architecture, and contemporary history: could you tell us about your archival work and how your research has nurtured your art?

DG : I think rather than nurture my art, the research that goes into it is as important as the image making itself (but not as much fun). The research is the foundation any series is based on and will sometimes take months until I understand what the question is, which I am attempting to answer with the work. Unfortunately I find it can go off at a tangent at any time and I can sometimes get lost in long intellectual corridors I shouldn't really have entered. It can sometimes take weeks to find a way out. I think the term for that is "easily sidetracked" !

IKP : Thank you very much to both of you for opening up for us the complex lens of your art and allowing us to get closer to this place where "we believed magic happened, like in the fairy tales."4

"This sequence of photographs comes from my East of Eden project which documents the path of the River Tees from its source in the High Pennines to the coast at Redcar, the title being a topographical truism as the river rises next to the Eden Valley and continues eastward to the sea. The photographs show how the landscapes that accompany the river reflect the cultural, economic, socio-political and industrial changes that have affected the North East over millennia and cut a deep, visible, historical time line through the area as they haveevolved and adapted to changing technologies and land use." David George

\section{NOTES}

1. Patrick Keiller, The View from the Train. Cities and Other Landscapes, London: Verso, 2014, 147-8.

2. David Gascoyne, Night Thoughts, A Radiophonic Poem, Paris: Alyscamps Press, 1995 (1956), p. 57.

3. Roberto Casati, La découverte de l'ombre. De Platon à Galilée, l'histoire d'une énigme qui a fasciné les grands esprits de l'humanité, Paris : Albin Michel, 2002. 
4. David George, Hackney by Night, London: Hoxton Mini Press, 2015, [n.p.].

\section{INDEX}

Subjects: Photography

Mots-clés: photographie, court métrage, peinture, banlieue, nature, paysage, le sublime, la pastorale, nostalgie, mémoire, ombres

Keywords: photography, short film, painting, suburbs, nature, landscape, the Sublime, the Pastoral, nostalgia, memory, shadows

\section{AUTHOR}

\section{ISABELLE KELLER-PRIVAT}

MCF HDR en études anglophones

Université Toulouse II - Jean Jaurès

isa.kellerprivat@free.fr 